\title{
Evaluating Urban Landscape Dynamics over Srinagar City and Its Environs
}

\author{
Arshad Amin, Shahab Fazal \\ Department of Geography, Aligarh Muslim University, Aligarh, India \\ Email: prince4321@gmail.com, essfazal@rediffmail.com
}

Received 27 February 2015; accepted 18 April 2015; published 22 April 2015

Copyright (C) 2015 by authors and Scientific Research Publishing Inc.

This work is licensed under the Creative Commons Attribution International License (CC BY). http://creativecommons.org/licenses/by/4.0/

(c) (i) Open Access

\begin{abstract}
Rapid, unplanned and uncontrolled urbanization causes disorganized growth. The patterns of urban development are changing natural landscapes and their dynamics. This has necessitated understanding of spatial patterns of urbanization and prompted research. Urbanization being a dynamic phenomenon has been facing ambiguities regarding methods to study its dynamism. It has made operational, a wide-variety of spatial metrics methods utilizing multiple dates of remotely sensed data. The present work carries out the quantitative and qualitative analysis of urban growth of Srinagar by using Urban Landscape Analysis Tool (ULAT). Urbanized Area (UA), Urban Footprint (UF) and New Development (ND) maps are generated to quantify the degree of urbanization based on spatial density of built-up area. Comparative analysis of these maps in relation to the built-up spread pattern indicates that mostly the environs of the Srinagar city which includes mostly agricultural, vacant and marshy areas prominently in northern, western and southern areas contribute to the development of the city.
\end{abstract}

\section{Keywords}

Urbanization, Landscape Dynamics, Urban Footprint, Urbanized Area, New Development

\section{Introduction}

Urbanization has become a widespread phenomenon throughout the world [1]. The global urban population has increased from 13\% (220 mi) in the year 1990 to 49\% (3.2 bi.) in 2005. Due to continued urbanization and overall growth, 2.5 billion people will be added to the urban population by 2050 [2]-[4]. This increase will be concentrated in the developing countries. Presently more than half of the world's population (54\%) is living in urban areas. India, being a developing country had 79 mi people living in the urban areas in the year 1961 which increased to $377 \mathrm{mi}$ in 2011 [5]. The rapid urbanization in India is because of the development in economy and 
industrialization. This has resulted into the expansion of its urban areas [6]. Over the first half of 20th century, growth in Indian cities remained largely confined within municipal boundaries. Increasing population growth and migration to the cities is accommodated by the existing urban areas rather than by expansion of cities into suburbs and fringe areas [7]. However from the past number of decades, the pattern of growth and absorption of population has considerably changed [8] and significant growth in urban areas has been witnessed [9]. Such a real expansion is mostly unplanned, [10] [11] characterized by low density, leap frog, and discontinuous development of built-up land use [12] [13]. This situation has led to loss of various land use/cover features e.g., fertile agricultural land [14]-[16], and today this becomes a burning issue which needs to be focused.

Therefore, understanding of such urban system and addressing questions regarding changes in spatio-temporal patterns of urban form are of paramount importance in urban studies [17]. Urban expansion needs to be monitored, quantified and understood for effective urban planning. This is possible by having the information about the current and historical land use and land cover [18] [19]. From time to time, urban researchers have tried to evaluate and characterize urban sprawl exclusively based on major socio-economic indicators such as population growth, commuting costs, employment shifts and number of commercial establishments [20]-[23]. However, these approaches do not identify and quantify the impacts of urban expansion in a spatial metrics which is of prime importance for urban studies. The recent availability of temporal remotely sensed data helps in detecting the urban landscape dynamics in relation to urbanization [24]-[26]. The temporal dynamics information aided with spatial models provides insights in to the urbanization pattern, assuring sustainable regional development [15] [27] [28]. Such spatial landscape models aids in assessing the spatial structure and composition of urban footprints which necessitates mapping and monitoring of urban footprint through quantification of paved surface (built up, roads, etc.) [29].

\section{Study Area}

The present study is done for Srinagar city which lies between $33^{\circ} 59^{\prime} 14^{\prime \prime} \mathrm{N}$ and $34^{\circ} 12^{\prime} 37^{\prime \prime} \mathrm{N}$ latitude and $74^{\circ} 41^{\prime} 06^{\prime \prime} \mathrm{E}$ and $74^{\circ} 57^{\prime} 27^{\prime \prime E}$ longitude. The city is located on both sides of the River Jhelum, locally called Vyeth in Kashmir (Figure 1), spreads between the plains of vale of Kashmir. It represents one of the, ecologically fragile, economically developing, tectonically unstable and densely populated mountain ecosystems on the planet.

The general relief of the study area is $1580 \mathrm{~m}$ above mean sea level. The general terrain is moderate and represents hill topography. Presently, it is the summer capital of the state of Jammu and Kashmir and has grown with time and gained primacy in terms of functions associated with politics, administration, commerce, economic development and tourism etc. The population of Srinagar city in 1951 was 255,679 which increased up to 952,324 in 2001, recording a growth of +51.06 per cent. As per 2011 census it has the total population of 1.24 million. With the onset of urbanization, the city witnessed economic changes instigating transformations in its land use pattern.

\section{Data Sets and Methodology}

The study is mainly based on secondary sources of data; the data used for the preparation of previous date land use/land cover of the study area is Landsat MSS of 1980 satellite imagery (Table 1, Figure 2). Similarly, the land use/land cover for the later date was carried out using IRS-1D LISS III + PAN 2012 merged satellite imagery.

\subsection{Processing of Raster Data}

Remotely sensed data was geo-referenced, geo-corrected, rectified and cropped pertaining to the study area (Municipal limits of Srinagar city) in Earth Resource Data Analysis System (ERDAS) Imagine 2014 software. Geo-registration of remote sensing data (LANDSAT MSS of 1980 and IRS-1D LISS III + PAN 2012) was done using ground control points collected from the field with the help of pre calibrated GPS (Global Positioning System) and known points from geo-referenced topographic maps published by the Survey of India. Image-toimage registration has been performed to bring the entire image in the same geometry using Universal Transverse Mercator (UTM) as its projection and WGS 84 as its datum with sub-pixel accuracy. Satellite imagery was stacked into different bands to produce a false color composite. The data pertained to the month of October 


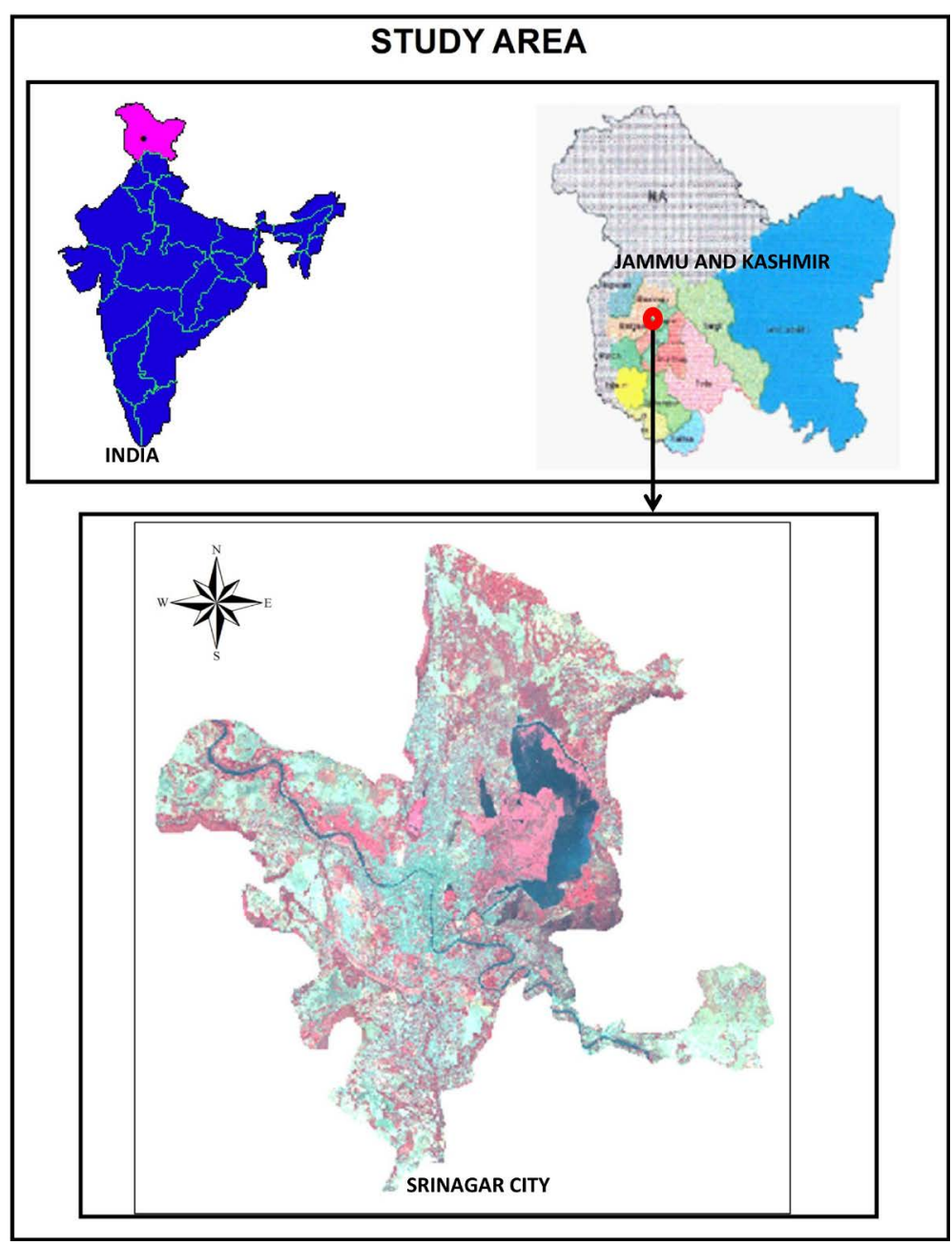

Figure 1. Location map of study area.

Table 1. Details of satellite data used in the study.

\begin{tabular}{|c|c|c|c|c|c|c|c|}
\hline S. No. & Data used & Path/row & Date of pass & $\begin{array}{c}\text { Wave length } \\
\text { width in } \mu \mathrm{m} / \mathrm{band}\end{array}$ & $\begin{array}{l}\text { Spatial resolution } \\
\text { (meters) }\end{array}$ & Swath (km) & Purpose \\
\hline 1 & $\begin{array}{l}\text { LANDSAT MSS } \\
\text { of } 1980\end{array}$ & $92 / 46$ & 02-10-1980 & $\begin{array}{c}0.5-0.6 \\
0.6-0.7 \\
0.7-0.8 \\
0.8-1.1 \\
10.41-12.6\end{array}$ & 57.5 & 185 & $\begin{array}{l}\text { Land use and land } \\
\text { cover mapping }\end{array}$ \\
\hline 2 & $\begin{array}{l}\text { IRS-1D } \\
\text { LISS-III }\end{array}$ & $92 / 46$ & $10-10-2012$ & $\begin{array}{l}0.52-0.59 \\
0.62-0.68 \\
0.77-0.86 \\
1.55-1.70\end{array}$ & 23.5 & 142 & $\begin{array}{l}\text { Land use and land } \\
\text { cover mapping }\end{array}$ \\
\hline 3 & $\begin{array}{l}\text { IRS-1D } \\
\text { PAN }\end{array}$ & $92 / 46$ & $10-10-2012$ & $0.5-0.75$ & 5.8 & 70 & $\begin{array}{l}\text { Land use and land } \\
\text { cover mapping }\end{array}$ \\
\hline 4 & $\begin{array}{l}\text { Survey of India (SOI) } \\
\text { toposheets of } 1: 50,000 \\
\text { and 1:250,000 scales }\end{array}$ & -- & -- & -- & -- & -- & $\begin{array}{l}\text { To generate boundary } \\
\text { and Base layer maps }\end{array}$ \\
\hline 5 & $\begin{array}{l}\text { Field visit data- } \\
\text { captured using GPS }\end{array}$ & -- & -- & -- & -- & -- & $\begin{array}{c}\text { For geo-correcting and } \\
\text { generating validation } \\
\text { dataset }\end{array}$ \\
\hline
\end{tabular}




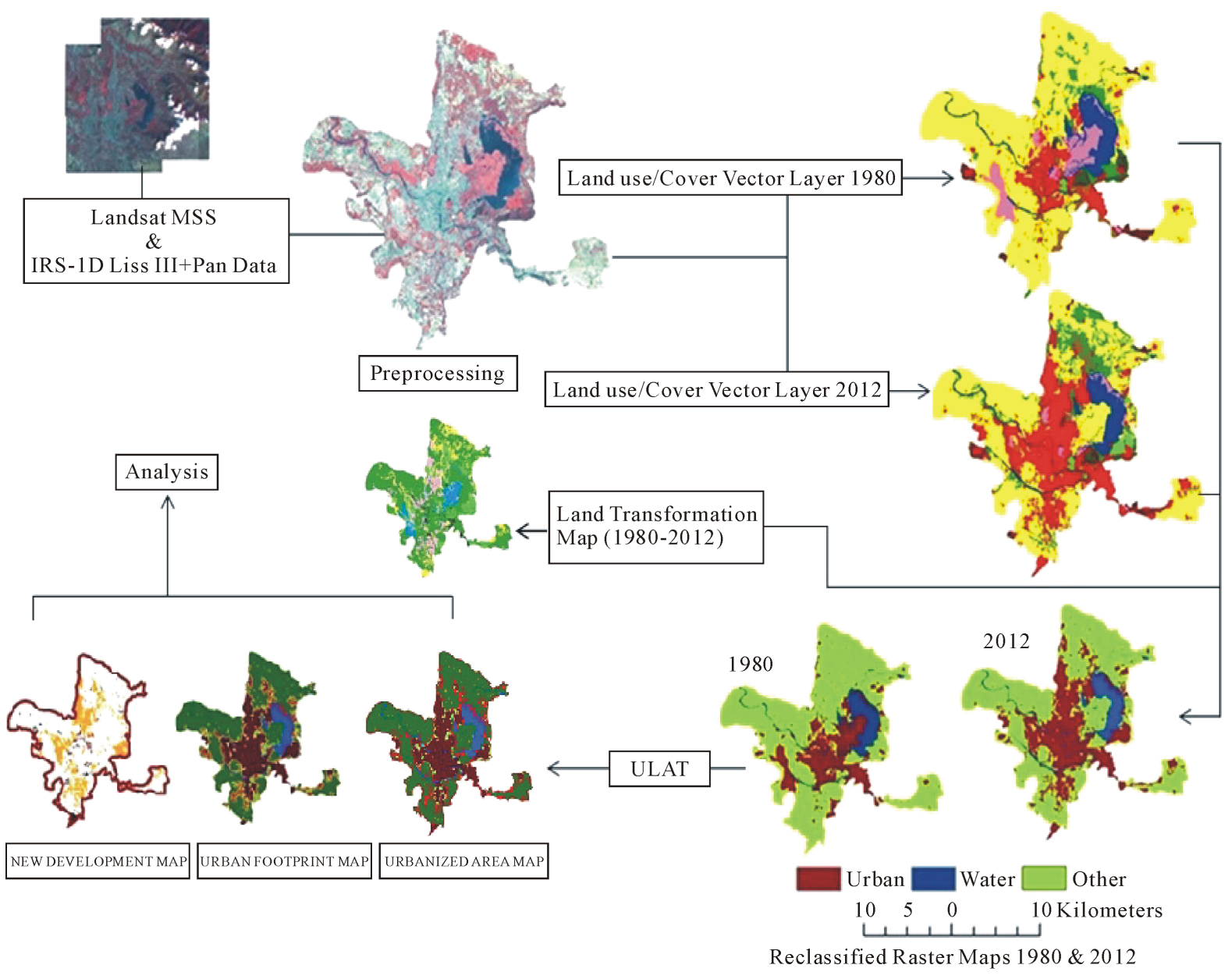

Figure 2. Methodology for evaluating urban landscape.

which corresponds to Kharif season.

\subsection{Processing of Vector Data}

These images were digitized in GIS environment using ArcGIS 10 software in the form of polygons representing different land use land cover categories. Reference to legacy data and other ancillary information has been used for precise interpretation of land use classes and delineation of the same. Land use/cover classification was based on National Remote Sensing Center (NRSC) classification (Level 1). The maps were put to further processing like area estimation, map composition and output generation. The data was classified into 9 land use/land cover classes spread over a total area of 23,446 hectares of the Srinagar city (which incidentally is also the $\mathrm{Mu}-$ nicipal limit). Further the land transformation analysis was carried out by superimposing of two time period land use/cover maps.

\subsection{Thematic Accuracy}

Accuracy assessment was done for the study area. All the Land Use Land Cover categories were numbered map-wise and sample chosen for field verification using the followingEquation (Jensen 1986):

Sample Size

$$
\mathrm{N}=4 \mathrm{pq} / \mathrm{E} 2
$$

where $\mathrm{p}$ is the expected percent accuracy (90\%), q' = difference between 100 and $\mathrm{p}$. E is the allowable error, and $\mathrm{N}$ the number of points to be sampled. 


\subsection{Urban Growth Analysis}

The study also analyzed urban growth using urban growth model developed by Center for Land use Education and Research (CLEAR) and the University of Connecticut Department of Natural Resources and the Environment USA.

\section{Results and Discussions}

\subsection{Land Use/Cover of Srinagar City}

To understand the magnitude of sprawl, land use/cover patterns of 1980 and 2012 were studied. Total number of nine land use/land cover classes was mapped, spread over 23,446 hectares of study area (which is the municipal limit). These classes include, built-up, Parks/gardens \& playgrounds, vacant, agriculture, plantation/orchards, forest, barren, marshy and water body (Figure 3 and Figure 4). The statistics derived out of different land use/

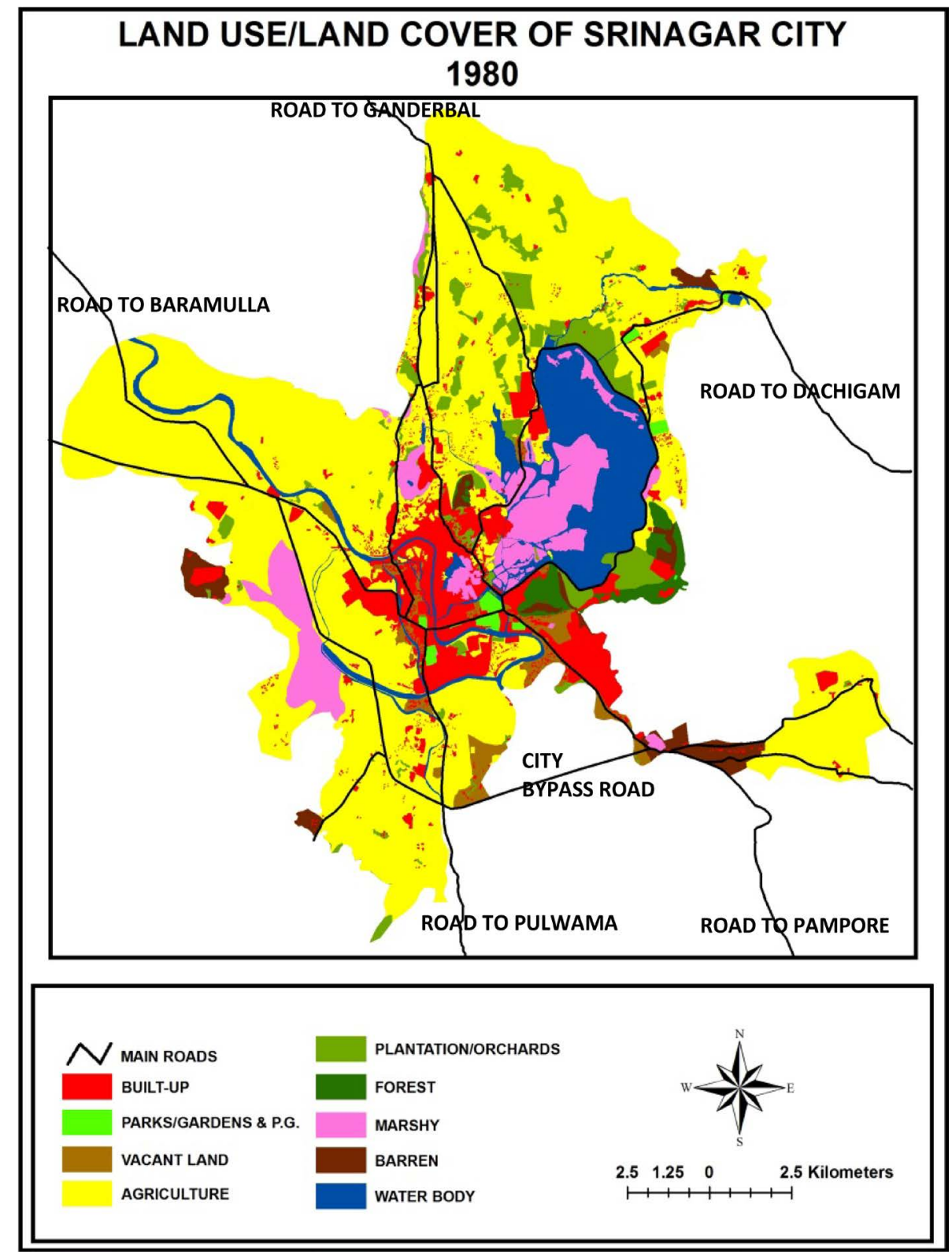

Figure 3. Land use/cover of Srinagar city 1980. 


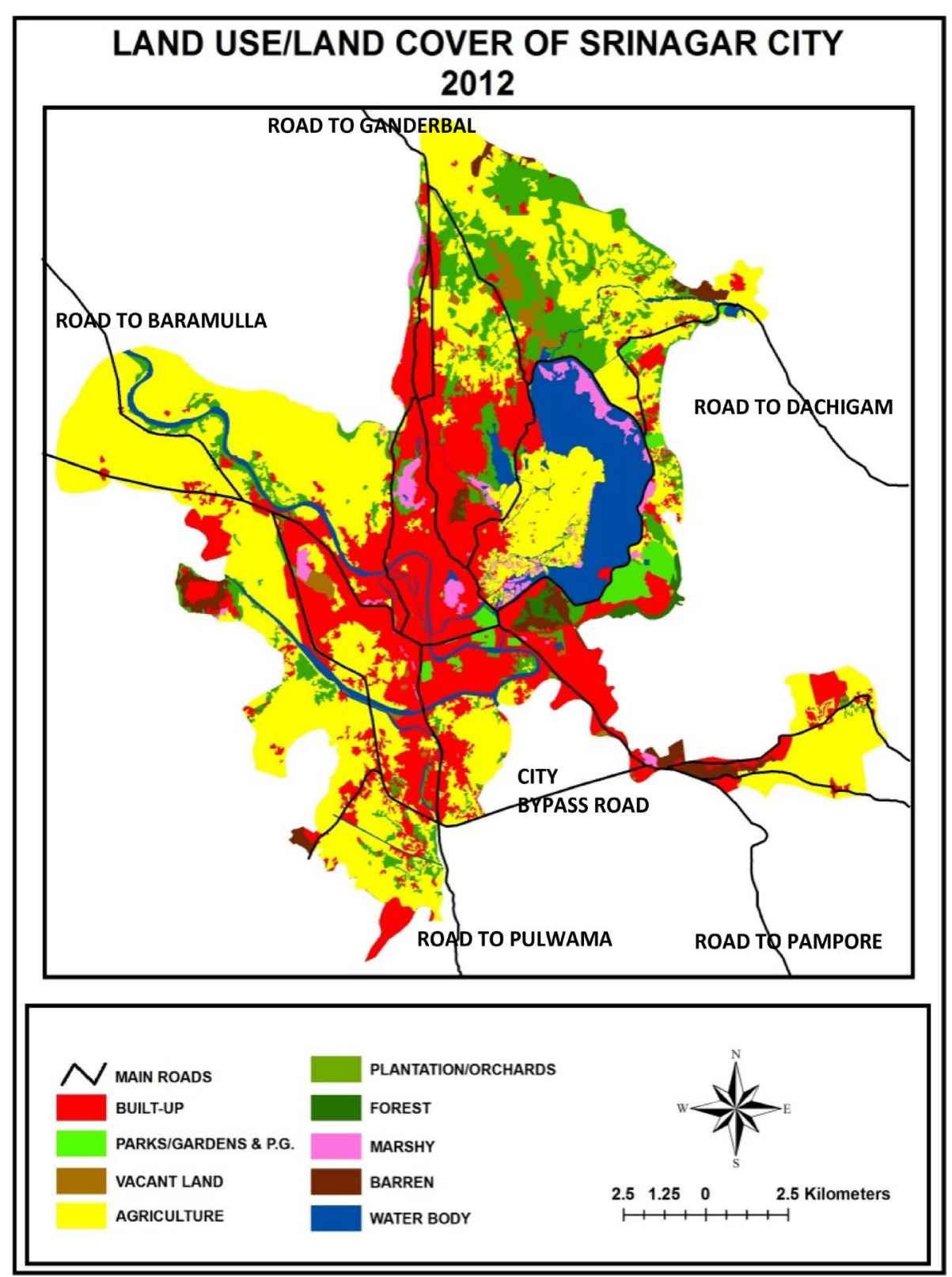

Figure 4. Land use/cover of Srinagar city 2012.

cover classes is given in Table 2 and their detailed explanation is as follows:

Built-up area has increased from 2416 hectares (10.30\% of the total area) in 1980 to 6251 hectares (26.66\% of the total study area) in 2012 (increase of 158 percent). The general trend of built-up expansion was observed in north, south and west directions only because the area lying in the east is occupied by water body. The increase is attributed to the increasing population due to natural increase and in-migration from the adjoining districts to the city, mostly from north and south. Also the development made in secondary and tertiary sectors resulted into residential, commercial and industrial development in the city. Similarly, the area under parks/gardens and playgrounds increased from 1.40 hectares ( $0.59 \%$ of the total study area) in the year 1980 to 3.72 hectares $(1.59 \%$ of the total study area) in 2012. Despite decrease in non-built-up area the total area under parks/gardens has increased by 232 hectares. This is mainly due to Srinagar city being a tourist spot and hence form an important part of the city's tourism.

Apart from increases, decrease was recorded in vacant land. It decreased from 517 hectares $(2.2 \%$ of the total 
Table 2. Srinagar city: land use/land cover (1980 \& 2012).

\begin{tabular}{|c|c|c|c|c|}
\hline Land use/land cover & $\begin{array}{c}1980 \\
\text { (Area in hectares) }\end{array}$ & $\begin{array}{c}2012 \\
\text { (Area in hectares) }\end{array}$ & $\begin{array}{l}\text { Area change } \\
\text { (in hectares) }\end{array}$ & $\begin{array}{c}\% \\
\text { Age change }\end{array}$ \\
\hline Built-up area & $\begin{array}{c}2416 \\
(10.3 \%)\end{array}$ & $\begin{array}{c}6251 \\
(26.66 \%)\end{array}$ & 3835 & 158 \\
\hline Parks/gardens \& playground & $\begin{array}{c}140 \\
(0.59 \%)\end{array}$ & $\begin{array}{c}372 \\
(1.59 \%)\end{array}$ & 232 & 165.7 \\
\hline Vacant & $\begin{array}{c}517 \\
(2.2 \%)\end{array}$ & $\begin{array}{c}255 \\
(1.08 \%)\end{array}$ & -262 & -50.6 \\
\hline Agriculture & $\begin{array}{c}14408 \\
(61.45 \%)\end{array}$ & $\begin{array}{c}10949 \\
(46.7 \%)\end{array}$ & -3459 & -24 \\
\hline Plantation/orchard & $\begin{array}{c}1266 \\
(5.40 \%)\end{array}$ & $\begin{array}{c}2622 \\
(11.18 \%)\end{array}$ & 1355 & 107 \\
\hline Forest & $\begin{array}{c}346 \\
(1.47 \%)\end{array}$ & $\begin{array}{c}153 \\
(0.65 \%)\end{array}$ & -193 & -55 \\
\hline Barren & $\begin{array}{c}539 \\
(2.3 \%)\end{array}$ & $\begin{array}{c}480 \\
(2.05 \%)\end{array}$ & -059 & -11 \\
\hline Marshy & $\begin{array}{c}1667 \\
(7.1 \%)\end{array}$ & $\begin{array}{c}468 \\
(2 \%)\end{array}$ & -1199 & \\
\hline Water body & $\begin{array}{c}2145 \\
(9.15 \%)\end{array}$ & $\begin{array}{c}1895 \\
(8.08 \%)\end{array}$ & -250 & -11.6 \\
\hline Total & 23,446 & 23,446 & & \\
\hline
\end{tabular}

study area) in 1980 to 255 hectares (1.08\% of the total study area) in 2012. This class includes the land belonging mostly to locals who have left crop cultivation and most of which is speculative land holding. The abandoned government land is also included in this category. The decrease is because of increasing population pressure in the core area compelling rich people to move to these vacant lands. This has resulted into the emergence of residential colonies in the outskirts of the city. Another important land use/cover category is agricultural land. The area under this class has also decreased from 14,408 hectares ( $61.45 \%$ of the total study area) to 10,949 hectares (46.7\% of the total study area) in 2012. It includes mostly paddy land, floating/vegetable gardens (Radh) and saffron karewa fields spread all over the study area except the core part of the city. This class has witnessed significant changes during the study period of 32 years by losing 3459 hectares. This decrease is attributed to the occupational shift of farmers from primary to secondary and tertiary activities. The shift from crop cultivation to horticulture activities have also contributed to the decrease of total land area under agriculture. Although agriculture is an important component of the region's economy therefore this class still covers large share of the total land use of the study area.

Despite decrease in the area under non-built-up land use/cover the total area under plantation/orchard class increased from 1266 hectares to 26.22 hectares (increased by 1355 hectares) from 1980 to 2012. This class includes willow plantation, apple, cherry, almond, walnut orchards, which are spread all over the study area in scattered patches except the core area. The increase is because of two reasons; firstly, farmers shifted from the traditional crop cultivation to the horticulture activities i.e., production of timber and various fruits like Apple, Cherry, Almonds, Apricot, Walnut etc., which is remunerative than the traditional food crop cultivation. Secondly, the annual threat of floods in the low lying area prominently in the west and south forced the farmers to opt for horticulture activities. Forest class decreased from 346 hectares (1.47\% of the total study area) to 153 hectares $(0.65 \%$ of the total study area). It includes the vegetation cover in the hilly areas of the city. Similarly, barren class which includes the bare exposed rocks, along with some quarrying sites has decreased from 539 hectares to 480 hectares, losing 59 hectares during the study period.

Significant changes have been observed in Marshy land use and water bodies which are ecologically important land use/cover features. The area under these categories was reduced by 1198 hectares and 250 hectares respectively. The prominent water bodies of the study area are Dal lake, BrariNambal, Nigeenlake, Khushalsar and Aanchar lake. The major reason for this is encroachment in these areas due to increasing demand from the 
growing population. Most of the encroachments in the Marshy areas and water bodies are un-authorized developments with the low standard of living of the people due to low level of income. It is an alarming environmental issue where government regulations are commonly violated.

\subsection{Land Transformations in Srinagar City}

Land Transformation is the process where changes in land use/cover are observed at different time periods. This process is one of the important fields of human induced environmental transformation. Land is in a continuous state of transformation as a result of various natural and man-made processes. Apart from land use/cover change, Srinagar city experienced significant interchange of land between different classes during the study period which is because of economic and social transformations. Table 3 and Figure 5 shows the interchange of various land use classes of the city. The development and expansion of the city has led to increase in demand for various built up land e.g., residential, commercial, industrial purposes etc.

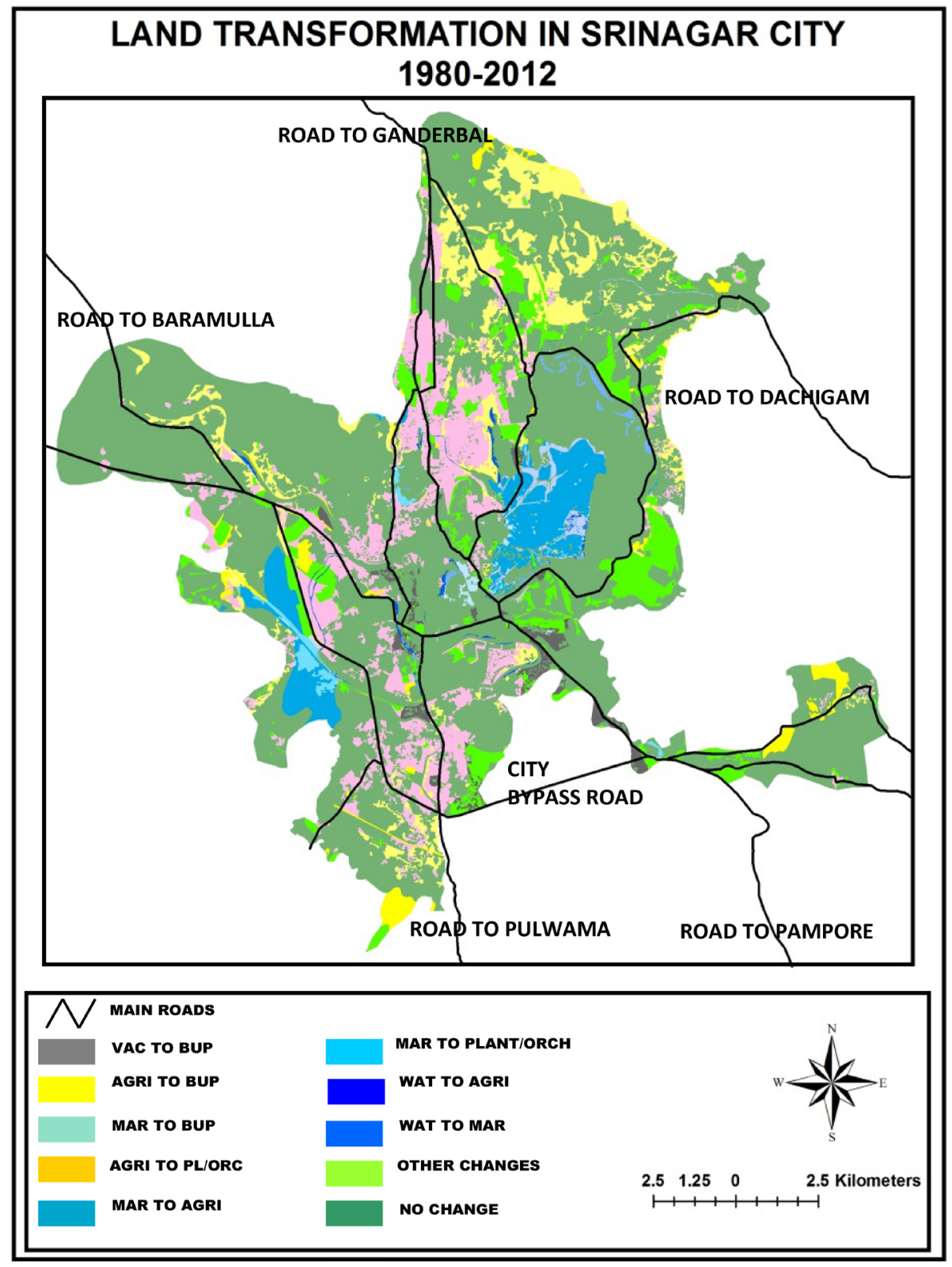

Figure 5. Land transformations in Srinagar city 1980-2012. 
Table 3. Land transformation in Srinagar city (1980-2012).

\begin{tabular}{|c|c|c|c|c|c|c|c|c|c|c|}
\hline Land use & $\begin{array}{c}1 \\
\text { Bup }\end{array}$ & $\begin{array}{c}2 \\
\text { Prk }\end{array}$ & $\begin{array}{c}3 \\
\text { Vac }\end{array}$ & $\begin{array}{c}4 \\
\text { Agr }\end{array}$ & $\begin{array}{c}5 \\
\text { Pl/Orc }\end{array}$ & $\begin{array}{c}6 \\
\text { For }\end{array}$ & $\begin{array}{c}7 \\
\mathrm{Bar}\end{array}$ & $\begin{array}{c}8 \\
\text { Mar }\end{array}$ & $\begin{array}{c}9 \\
\text { Wat }\end{array}$ & $\begin{array}{c}\text { Total } \\
\text { area } \\
\text { (2012) }\end{array}$ \\
\hline 1) Built-up & 2416 & & 385 & 2932 & 258 & 71 & 59 & 126 & 03 & 6251 \\
\hline 2) Parks \& gardens & & 140 & & & 149 & 83 & & & & 372 \\
\hline 3) Vacant & & & 517 & 185 & 685 & & & & & 255 \\
\hline 4) Agriculture & & & 109 & 14,408 & 214 & & & 10,415 & 148 & 10,949 \\
\hline 5) Plantation/orchards & & & 215 & 1854 & 1266 & 39 & & 88 & 42 & 2622 \\
\hline 6) Forest & & & & & & 346 & & & & 153 \\
\hline 7) Barren & & & & & & & 539 & & & 480 \\
\hline 8) Marshy & & & & & & & & 1667 & 92 & 468 \\
\hline 9) Water body & & & & & & & & 35 & 2145 & 1895 \\
\hline
\end{tabular}

Note: Area in hectares. Figures in bold (diagonally) are area under that particular land use in 1980, while the figures in the same column represent the conversion in area to other land uses. Similarly, figures in the same row are increases in area, captured from other land uses; Source: Based on IRS1D LISS + PAN Satellite imagery (2012) and LANDSAT MSS of 1980 of Srinagar city.

Significant land transformations were witnessed among built-up area, vacant, plantation/orchards, agriculture, water bodies and marshy lands. Built-up area increased by 3835 hectares, capturing land mainly from agriculture (2932 hectares), vacant (385 hectares), plantation/orchards (258 hectares) and marshy area (126 hectares). Prominently residential class grabbed area mostly from agriculture because of growing demand from the increasing population. Parks/gardens and play grounds increased by 232 hectares, gaining area from plantation (149 hectares) and forest area (83 hectares). Apart from increase in the area under plantation/orchards there was loss of 689 hectares and this loss was gain for built-up, parks and gardens, and vacant area. Similarly, vacant land also lost its 262 hectares to built-up area for residential and commercial development and also for agriculture and horticulture development. Agriculture lost 3469 hectares of land for infrastructure development of the city in terms of residential, commercial, industrial, recreational and horticulture developments. Besides it, farmer gave up agricultural practice and sold their valuable land only for getting instant money. Also, in order to lift their social status they opt for non-farm activities. There are examples from the city where farmers have given up the traditional farming practices and shifted towards the plantation and orchard practices because farmers do not have knowledge regarding the modern agricultural inputs which has resulted into low agricultural efficiency. Therefore horticulture activities are the only option left with the farmers. The transformation process has not even spared the ecologically important land use/cover features i.e., water bodies and marshy areas which lost 1449 hectares mainly for agricultural, horticulture and infrastructure development of the city.

\subsection{Evaluation of Urban Footprint in Srinagar City}

Urban Footprint represents the evaluation for impact of development on open land around the city. This map consists of seven categories in the study area based on urbanness values (Table 4) and their land cover attributes. These categories are 1) Urban built-up (5357.23 ha), 2) Suburban built-up (1811.22 ha), 3) Rural built-up (167.60 ha), 4) Fringe open land (2363.02 ha), 5) Captured open land (249.93 ha), 6) Rural open land (11342.70 ha) and 7) water classes (2145 ha). The important category identified by footprint mapping is fringe open land, which acts as edge-disturbance zone. These are the regions at edge that are prone to degradation by adjacent land use.

Urban and suburban built-up land increased by 1996 and 618 hectares during 1980-2012 time span with resulting decrease of 2752 ha in rural open land. Urbanization of rural settlements has resulted in to decrease of 249 ha. This decrease is due to transformation of rural built-up to suburban and urban built-ups because of extension of urban services towards the city peripheral areas. Further, due to expansion and development during the study period an increase of 2363 and 249 ha was noticed for fringe and captured open lands (Figure 6 and Table 5). 


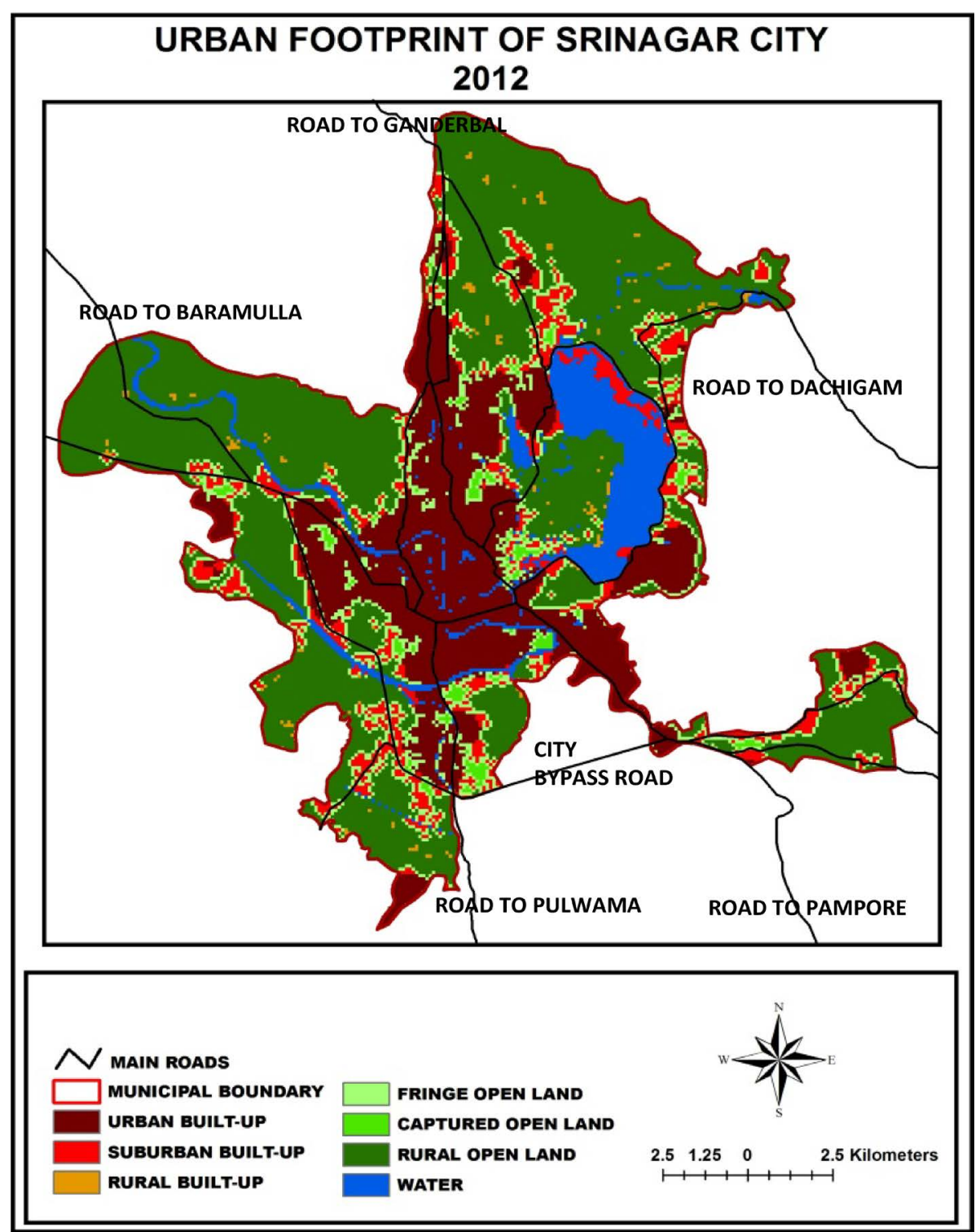

Figure 6. Urban footprint of Srinagar city 1980-2012.

Table 4. Urbanized area and urban footprint classes and criteria for their categorization.

\begin{tabular}{ccl}
\hline S. No. & Class & \\
\hline 1 & Urban footprint & Criteria \\
2 & Urban built-up & Built-up, $>50 \%$ urbanness \\
3 & Suburban built-up & Built-up, $10 \%-50 \%$ urbanness \\
4 & Rural built-up & Built-up, $<50 \%$ urbanness \\
5 & Fringe open land & Undeveloped, in 100 m of developed area \\
6 & Captured open land & Undeveloped patches (<200 ha), completely surrounded by urban built-up and fringe open land \\
7 & Rural open land & Undeveloped, neither fringe nor captured open land \\
8 & Water & Water in land cover classification \\
9 & Urbanized area & Urban built-up, suburban built-up, rural built-up, captured open land, rural open land \\
10 & Urbanized open land & Undeveloped urbanness $50 \%$
\end{tabular}


Table 5. Urban footprint of Srinagar city.

\begin{tabular}{cc}
\hline Land use & Area in hectares \\
\hline Captured open land & 249.93 \\
Fringe open land & 2363.02 \\
Rural built-up & 167.60 \\
Rural open land & 11342.70 \\
Suburban built-up & 1811.22 \\
Urban built-up & 5357.23 \\
Water & 2145 \\
\hline
\end{tabular}

\subsection{Evaluation of Urbanized Area of Srinagar City}

The study further analyzed the urbanized area classes to assess the impact of different levels of urbanization. Total number of seven classes were mapped for urbanized area; urban built-up (5357.23 ha), suburban built-up (1811.82 ha), rural built-up (167.70 ha), urbanized open land (840.93 ha), water (2145 ha), captured open land (840.93 ha), rural open land (13058.85 ha) (Figure 7 and Table 6). Urbanized open land is a class that is having maximum probability of high degradation of undeveloped land patches, present in between developed lands. New developments, converted large chunks of other classes such as rural open land to urbanized open lands. This resulted in increase of urbanized open lands from 1990 to 2012 by 396 ha during the study period of 32 years.

\subsection{New Development of Srinagar City}

The new development (ND) of Srinagar city represents the newly developed area during the study period. The analysis of New Development statistics revealed the pattern and type of urban growth that has taken place in the city. Greater part of new development is attributed to extension which accounts for more than $80 \%$ of developments. Leapfrog contributed 9.26\% to new development area and the rest $7.2 \%$ developed through infill (Figure 8 and Table 7).

Qualitative analysis of new development maps indicates that, the development in northern and western parts of the city has been dominated by extension process which could be attributed to coming up of new establishment of city outer core areas; Zoonimar, Maideen Sahib, Soura, Buchpora, Lal Bazar, Nowshera and Hazratbal in the north; Safakadal, Eidgah, Parimpora, Bemina, Qamarwari in the west; Baghat Barzulla, Rawalpora, Chanpora and Natipora in the south and Nishat, Khrew and Khonmoh area in the east and south east of the city respectively. However this process is more scattered over south, south eastern and eastern parts mainly because of the existing hill topography. Infill was found mainly in the city core area i.e., Kawdara, Hassnabad, Tarabal, Aalikadal, Nawab Bazar, Chattabal, JogiLankar, Khanyar and Rajbaghand few areas in south eastern parts of Srinagar city. Leapfrog development is prominent in the suburban Srinagar city. These are the scattered locations mainly in Malura, Lawaypora in the west and Humhama in the south.

\section{Conclusions}

The present work suggests that the urbanization process has significantly modified the land use of Srinagar city and its surrounding areas during the study period of 32 years. Built-up area has significantly increased by $158 \%$ swallowing the fertile agricultural land (3459 hectares) in the fringe area, where industrial and residential expansion is taking place. Similarly for the horticulture development $12.86 \%$ of fertile agricultural land is used. The city has expanded prominently toward northern, western and southern parts mainly due to the availability of land in these areas and the area lying in the east is occupied by water body and mountains. The study further demonstrates that the ecologically fragile land use/cover features i.e., marshy, forest area and water bodies have also decreased in their total area by $-71.8 \%,-55 \%$ and $-11.6 \%$ respectively for agricultural, residential and industrial development of the city. The increasing population leads to the decrease in per capita land availability 


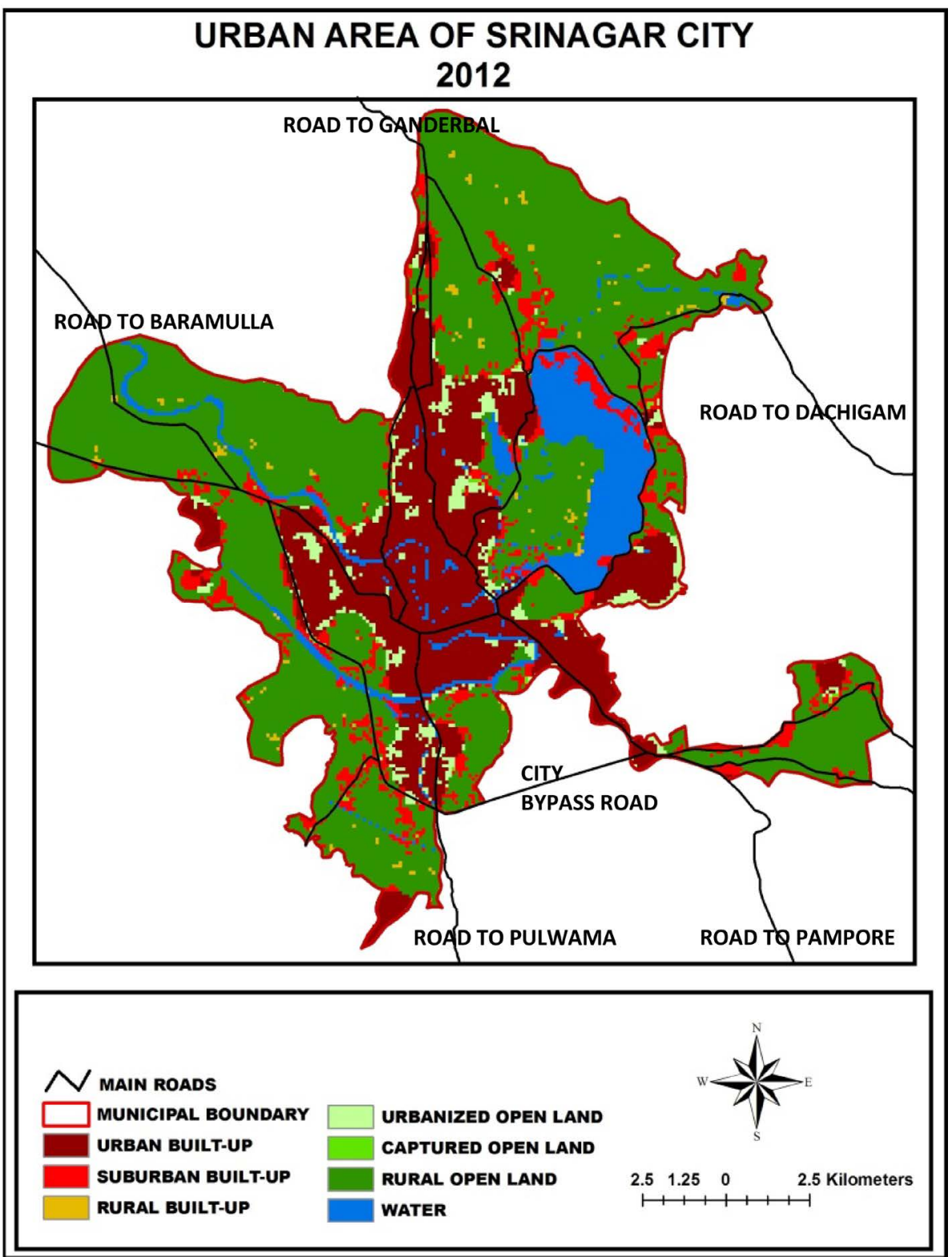

Figure 7. Urbanized area of Srinagar city 1980-2012.

Table 6. Urbanized area of Srinagar city.

\begin{tabular}{cc}
\hline Land use & Area in hectares \\
\hline Captured open land & 55.87 \\
Rural built-up & 167.60 \\
Rural open land & 13058.85 \\
Suburban built-up & 1811.22 \\
Urban built-up & 5357.23 \\
Urbanized open land & 840.93 \\
Water & 2145 \\
\hline
\end{tabular}




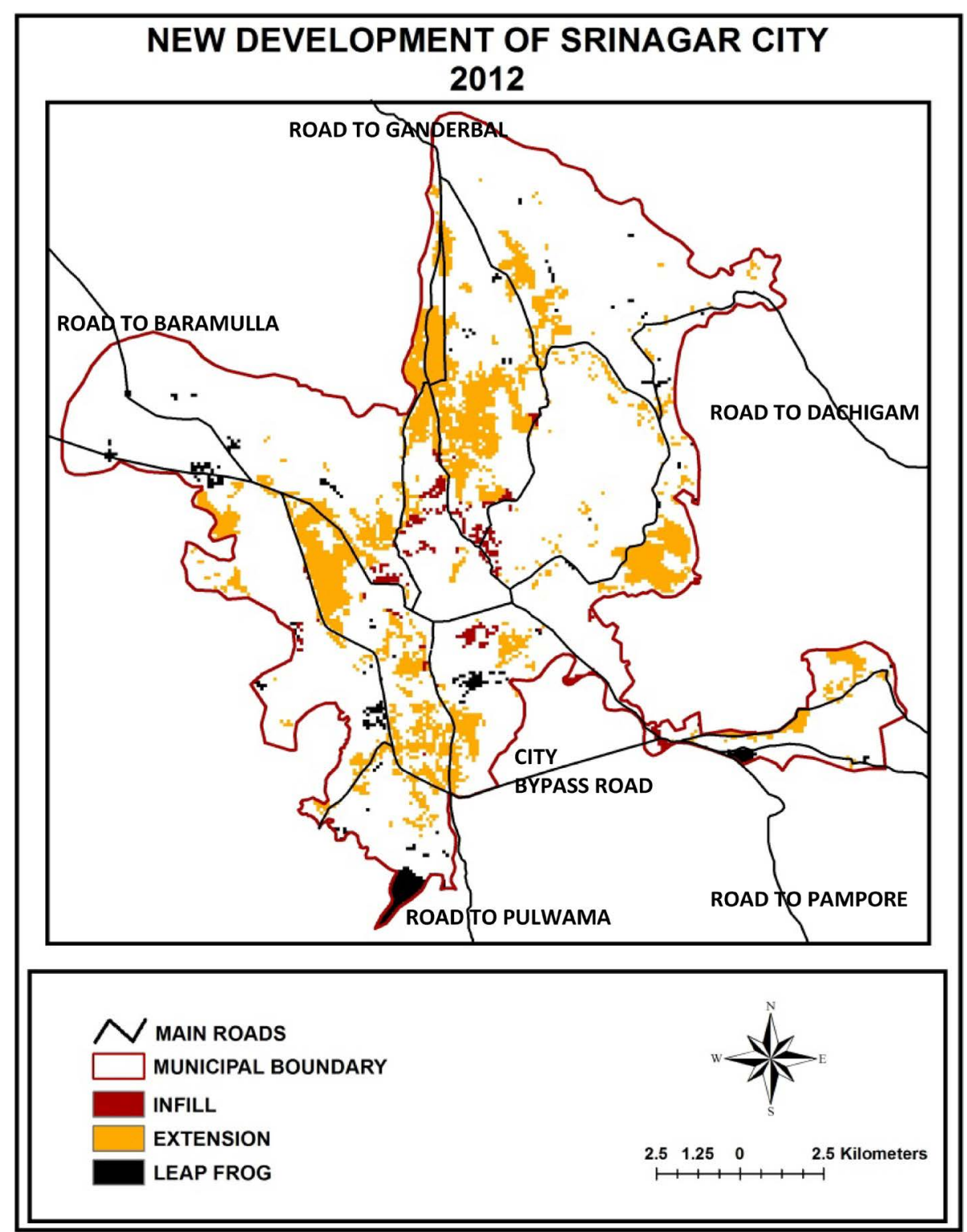

Figure 8. New development of Srinagar city.

Table 7. Srinagar city: new development-2012.

\begin{tabular}{ccc}
\hline & Classes & \% Development \\
\hline Infill & 295.01 & 7.29 \\
Extension & 3381.35 & 83.45 \\
Leapfrog & 375.38 & 9.26 \\
\hline
\end{tabular}

resulting into shortage of land and increase in rate of land transformation process.

The urban landscape analysis demonstrates that the expansion of built-up in the city has been mainly due to extension development accounting for $83.45 \%$ of total development. The urbanized area and urban footprint map statistics reveal that urban and suburban built-up increases by 1996 and 618 hectares during 1980-2012 time period with concurrent decrease of 2752 hectares in rural open land. The northern, western and the southern parts of the city develop mainly due to extension development. Infill and leapfrog development dominate in the 
core area and suburbs of the city respectively. The study clearly shows the trend and pattern of urban expansion in Srinagar city on rural open lands. Therefore, there is a need to identify, quantify and monitor the process of urbanization which can ensure the effective and sustainable urban planning by the authorities.

\section{References}

[1] Sharma, R. and Joshi, P.K., (2013) Monitoring Urban Landscape Dynamics over Delhi (India) Using Remote Sensing (1998-2011) Inputs. Journal of Indian Society of Remote Sensing, 41, 641-650. http://dx.doi.org/10.1007/s12524-012-0248-X

[2] Ramachandra, T.V. and Kumar, U. (2008) Wetlands of Greater Bangalore, India: Automatic Delineation through Pattern Classifiers. Electronic Green Journal.

[3] World Urbanization Prospects (2005) Revision, Population Division. United Nations Department of Economic and Social Affairs, New York.

[4] United Nations (2012) World Urbanization Prospectus: The 2011 Revision Highlights, New York.

[5] Muthusamy, N. and Ramalingam, M. (2003) Environmental Impact Assessment for Urban Planning and Development Using GIS. Proceedings of the 3rd International Conference on Environment and Health, Chennai, 15-17 December 2003, 290-299.

[6] Bhagat, R.B. (2011) Emerging Pattern of Urbanization in India. Economic and Political Weekly, 46, 10-12.

[7] Brush, J.E. (1968) Spatial Patterns of Population in Indian Cities. Geographical Review, 58, 362-691. http://dx.doi.org/10.2307/212563

[8] Shaw, A. (2005) Peri-Urban Interface of Indian Cities: Growth, Governance and Local Initiatives. Economic and Political Weekly, 40, 129-136.

[9] Shaw, A. (1999) Emerging Pattern of Urbanization in India. Economic and Political Weekly, 34, 17-30.

[10] Fazal, S. and Amin, A. (2011) Impact of Urban Land Transformation on Water Bodies in Srinagar City, India. Journal of Environmental Protection, 2, 142-153. http://dx.doi.org/10.4236/jep.2011.22016

[11] Liu, Y., Yue, W. and Fan, P. (2011) Spatial Determinants of Urban Land Conversion in Large Chinese Cities: A Case of Hangzhou. Environment and Planning B: Planning and Design, 38, 706-725. http://dx.doi.org/10.1068/b37009

[12] Ewing, R. (1997) Is Los Angeles-Style Sprawl Desirable? Journal of the American Planning Association, 63, 107-126. http://dx.doi.org/10.1080/01944369708975728

[13] Downs, A. (1999) Some Realities about Sprawl and Urban Decline. Housing Policy Debate, 10, 955-974.

[14] Fazal, S. (2014) Peri Urban Livelihood, Opportunities and Challenges. Concept Publications, New Delhi.

[15] Ramachandra, T.V., Aithal, B.H. and Sanna, D.D. (2012) Insights to Urban Dynamics through Landscape Spatial Pattern Analysis. International Journal of Applied Earth Observation and Geoinformation, 18, 329-343. http://dx.doi.org/10.1016/j.jag.2012.03.005

[16] Uttara, S., Bhuvandas, N. and Aggarwal, V. (2012) Impacts of Urbanization on Environment. International Journal of Research in Engineering and Applied Sciences, 2, 1637-1645.

[17] Amin, A. and Fazal, S. (2012) Land Transformation Analysis Using Remote Sensing and GIS Techniques (A Case Study). Journal of Geographic Information System, 4, 229-236. http://dx.doi.org/10.4236/jgis.2012.43027

[18] Zhang, C. and Zhang, S. (2002) Association Rule Mining. Models and Algorithms. Springer-Verlag, Berlin.

[19] Zhang, Q. and Seto, K.C. (2011) Mapping Urbanization Dynamics at Regional and Global Scales Using Multi Temporal DMSP/OLS Nighttime Light Data. Remote Sensing of Environment, 115, 2320-2329. http://dx.doi.org/10.1016/j.rse.2011.04.032

[20] Han, S.S. and He, C.X. (1999) Diminishing Farmland and Urban Development in China: 1993-1996. GeoJournal, 49, 257-267. http://dx.doi.org/10.1023/A:1007005015875

[21] Brueckner, J.K. (2000) Urban Sprawl: Diagnosis and Remedies. International Regional Science Review, 23, $160-171$. http://dx.doi.org/10.1177/016001700761012710

[22] Lucy, W. and Phillips, D. (2000) Confronting Suburban Decline: Strategic Planning for Metropolitan Renewal. Island Press, Washington DC.

[23] Chen, S., Zeng, S. and Xie, C. (2000) Remote Sensing and GIS for Urban Growth Analysis in China. Photogrammetric Engineering and Remote Sensing, 66, 593-598.

[24] Ji, C.Y., Lin, P., Li, X., Liu, Q., Sun, D. and Wang, S. (2001) Monitoring Urban Expansion with Remote Sensing in China. International Journal of Remote Sensing, 22, 1441-1455. http://dx.doi.org/10.1080/01431160117207

[25] Yeh, A.G.O. and Li, X. (2001) Measurement and Monitoring of Urban Sprawl in a Rapidly Growing Region Using 
Entropy. Photogrammetric Engineering and Remote Sensing, 67, 83-90.

[26] Hill, J., Hostert, P. and Roder, A. (2004) Long-Term Observation of Mediterranean Ecosystems with Satellite Remote Sensing. In: Mazzoleni, S., di Pasquale, G., Mulligan, M., Di Martino, P. and Rego, F., Eds., Recent Dynamics of the Mediterranean Vegetation and Landscape, John Wiley and Sons Ltd., Chichester, 33-43.

[27] DeFries, R. (2008) Terrestrial Vegetation in the Coupled Human-Earth System: Contributions of Remote Sensing. Annual Review of Environment and Resources, 33, 369-390.

[28] Bhatta, B. (2009) Analysis of Urban Growth Pattern Using Remote Sensing and GIS: A Case Study of Kolkata, India. International Journal of Remote Sensing, 30, 4733-4746. http://dx.doi.org/10.1080/01431160802651967

[29] Ramachandra, T.V., Bharath, H.A. and Sowmyashree, M.V. (2014) Urban Footprint of Mumbai-The Commercial Capital of India. Journal of Urban and Regional Analysis, 6, 71-94. 